\title{
Tinjauan Ekonomi Persentase Karkas Sapi Bali Berdasarkan Asal Ternak yang Dipotong di Rumah Pemotongan Hewan Mambal, Badung Bali
}

\author{
(ECONOMIC REVIEW OF BALI CATTLE CARCASS PERCENTAGE BASED ON \\ SLAUGHTERED LIVESTOCK ORIGIN IN MAMBAL ANIMALS SLAUGHTERHOUSE, \\ $B A D U N G B A L I)$
}

\author{
Devinda Yuniastika $^{1 *}$, Ketut Tono Pasek Gelgel ${ }^{2}$, Ida Bagus Kade Suardana ${ }^{3}$ \\ ${ }^{1}$ Praktisi Dokter Hewan di Kota Denpasar; \\ ${ }^{2}$ Laboratorium Mikrobiologi Veteriner Fakultas Kedokteran Hewan, Universitas Udayana \\ Jln. PB. Sudirman Denpasar Bali; \\ ${ }^{3}$ Laboratorium Virologi Veteriner Fakultas Kedokteran Hewan, Universitas Udayana Jln. PB. \\ Sudirman Denpasar Bali. \\ *Email: devinda591@gmail.com
}

\begin{abstract}
Abstrak
Sapi Bali dikenal memiliki persentase karkas yang tinggi. Penelitian ini bertujuan untuk mengetahui perbedaan persentase karkas sapi bali yang berasal dari daerah dataran tinggi dan dataran rendah yang dipotong di RPH Mambal, Kecamatan Abiansemal , Kabupaten Badung, Provinsi Bali dan untuk mengetahui harga jual karkas dari kedua daerah tersebut. Penelitian ini menggunakan masingmasing 56 ekor sapi bali asal Kabupaten Bangli dan Gianyar. Data berupa persentase karkas berdasarkan asal ternak dianalisa dengan menggunakan Uji Independent Samples T Test untuk melihat ada tidaknya perbedaan. Hubungan antara berat hidup dan berat karkas sapi bali serta harga jual total digunakan analisis regresi power (Sampurna, 2012). Hasil penelitian menunjukkan persentase karkas lebih tinggi di Kabupaten Bangli, sehingga menimbulkan harga jual yang lebih tinggi dan lebih menguntungkan.
\end{abstract}

Kata kunci: Persentase karkas; asal ternak; rumah potong hewan; harga jual.

\begin{abstract}
Bali cattle are known to have a high percentage of carcasses. This study aims to determine the percentage of bali cattle carcasses from highland and lowland areas that were slaughtered in RPH Mambal Abiansemal district, Badung regency, Bali province, and to find out the selling price of carcasses from both regions. This study used 56 bali cattle from Bangli and Gianyar regencies. Data on the percentage of carcass based on animal origin were analyzed using Independent Samples T-Test to see whether there were differences. The relationship between life weight and carcass weight of Bali cattle and the total selling price is used by power regression analysis (Sampurna, 2012). The results showed a higher percentage of the carcass in Bangli Regency, resulting in higher and more profitable selling
\end{abstract}

Keywords: Carcass percentage; animal origin; animal slaughter house; selling price.

\section{PENDAHULUAN}

Sapi bali (Bos sondaicus) saat ini menjadi salah satu penyedia daging sapi bagi konsumsi di Indonesia (Besung et al., 2019). Daging sapi Bali dikenal memiliki persentase karkas mencapai $60 \%$ (Sriwijayanti et al., 2012). Karkas merupakan produk pemotongan ternak yang mempunyai nilai ekonomi tinggi
(Subekti et al., 2012). Karkas adalah bagian tubuh ternak yang telah disembelih hingga keluar semua darah dan cairan tubuh serta dipisahkan dari kepala, kaki, kulit, ekor dan jeroan. Dari karkas diperoleh daging yang merupakan bahan pangan berkualitas dan harganya tinggi. Produktivitas seekor sapi dapat dikatakan baik apabila menghasilkan karkas yang 
banyak dengan kualitas yang baik. Kualitas karkas dipengaruhi oleh jenis ternak, jenis kelamin, pakan dan teknologi pakan, serta penanganan ternak sebelum pemotongan (Saka et al., 2011; Agustina et al., 2017).

Hasil penelitian tahun 1995, menunjukkan bahwa berat sapi dewasa asal daerah dataran tinggi lebih tinggi dibandingkan sapi asal daerah dataran rendah dan perbedaannya nyata pada sapi jantan. Secara keseluruhan berat sapi jantan dewasa rata-rata mencapai $394 \mathrm{~kg}$ dan pada sapi betina $304 \mathrm{~kg}$. Data ini menunjukkan adanya "antiklimaks" terhadap kecenderungan penurunan berat badan, mungkin disebabkan karena adanya pembinaan yang intensif, seperti perbaikan mutu genetik, mutu pakan, manajemen dan lain-lain (Guntoro et al., 1997)

Efisiensi produksi usaha sapi potong tercermin dari produksi karkas dengan persentase tinggi dan kualitas karkas yang baik (Yosita et al., 2012). Informasi ini berguna untuk pengepul sapi, pengusahapengusaha daging olahan atau pengecer daging agar dapat memenuhi persyaratanpersyaratan yang diminta konsumen dalam hal persentase karkas dan non karkas, besarnya potongan karkas, daya tarik dan komposisi potongan karkas atau produk yang ditawarkan untuk memberikan keuntungan yang layak. (Kempster et al., 1982). Berkaitan dengan hal tersebut perlu dilakukan penelitian persentase karkas sapi bali berdasarkan asal daerah yang dipotong di RPH Mambal.

\section{METODE PENELITIAN}

Objek yang digunakan dalam penelitian ini adalah sapi bali yang dipotong di Rumah Pemotongan Hewan (RPH) Mambal yang berasal dari Kabupaten Bangli mewakili daerah dataran tinggi dan dari Kabupaten Gianyar mewakili daerah dataran rendah masing - masing diambil 56 sample, total 112 sample. Penelitian bersifat observatif dengan mengumpulkan data dari sapi bali yang dipotong di RPH Mambal yang berasal dari Bangli yang mewakili daerah dataran tinggi dan
Gianyar yang mewakili daerah dataran rendah. Metode yang digunakan dalam penelitian ini dilakukan dengan pengumpulan data primer. Data primer didapat dari hasil wawancara dengan petugas $\mathrm{RPH}$ Mambal dan pengamatan langsung di lapangan.

Variabel penelitian yang akan dikaji dalam penelitian ini dibagi menjadi tiga yaitu variabel terikat adalah persentase karkas, variabel bebas (variabel independen) yaitu daerah asal ternak, dan variable kendali yaitu faktor internal berupa jenis kelamin dan umur, sedangkan faktor eksternal berupa jenis pakan, cara pemeliharaan, dan penyakit. Sapi Bali yang datang ke RPH Mambal dicatat asal daerahnya, yaitu daerah Bangli yang mewakili dataran tinggi dan daerah Gianyar mewakili dataran rendah. Selanjutnya dilakukan penimbangan untuk menentukan bobot hidup. Sapi Bali disembelih dengan terlebih dahulu dengan direbahkan, kemudian bagian karkas dan non karkas seperti kepala, kulit, ekor, jeroan, dll dipisahkan. Karkas dikemas dan ditimbang begitu juga non karkas ditimbang. Setelah mengetahui bobot hidup dan bobot karkas dan non karkas, maka didapat persentase karkas dan non karkas. Selanjutnya dapat ditentukan harga jual karkas. Data berupa persentase karkas berdasarkan asal ternak dianalisa dengan menggunakan Uji Independent Samples T Test untuk melihat ada tidaknya perbedaan. Hubungan antara berat hidup dan berat karkas sapi bali serta harga jual total digunakan analisis regresi power (Sampurna, 2012). Penelitian ini dilaksankan pada bulan April - Mei 2018, bertempat di Rumah Potong Hewan Mambal.

\section{HASIL DAN PEMBAHASAN}

\section{Persentase karkas sapi bali berdasarkan daerah asal ternak}

Berdasarkan hasil uji independent samples t-test, persentase karkas memiliki nilai Sig. (2- tailed) sebesar 0,00 yang berarti terdapat perbedaan yang sangat 
signifikan antara sapi bali yang berasal dari Kabupaten Gianyar dibandingkan dengan sapi yang berasal dari Kabupaten Bangli dengan nilai rerata (mean) sebesar $47,8 \%$ pada sapi bali asal Gianyar dan $50,4 \%$ pada sapi asal Bangli (Tabel 1).

Sementara berdasarkan hasil uji regresi (Tabel 2) pengaruh berat hidup terhadap berat karkas maka dapat dibuat rumus harga jual karkas sapi bali sebagai berikut: Berat Karkas Sapi Gianyar $=0.420$ (berat hidup ${ }^{1.022}$ ). Berat Karkas Sapi Bangli = 0.336 (berat hidup 1.072). Apabila harga karkas di pasaran Rp 80.000, maka dapat dibuat rumus harga jual total karkas sebagai berikut: Harga Jual Karkas Sapi Gianyar $=0.420$ (berat hidup 1.022 ) adalah
Rp. 80.000, sementara harga Jual Karkas Sapi Bangli $=0.336$ (berat hidup 1.072) adalah Rp. 80.000.

\section{Harga jual total karkas sapi bali berdasarkan daerah asal ternak}

Hubungan antara berat hidup dengan berat karkas dimuat dalam Gambar 1 . Sementara pada Gambar 2 diketahui bahwa berat hidup sapi bali dengan berat yang sama berpengaruh terhadap berat karkas yang menyebabkan pengaruh terhadap persentase karkas. Berat karkas sapi bali yang berasal dari daerah Bangli lebih tinggi dibandingkan sapi bali yang berasal dari daerah Gianyar. Harga jual karkas sapi bali dari Kabupaten Gianyar dan Kabupaten Bangli.

Tabel 1. Uji Independent Samples T-Test

\begin{tabular}{|c|c|c|c|c|c|}
\hline Variabel & Asal Ternak & $\mathrm{N}$ & Mean & Std. Dev. & Sig. (2-tailed) \\
\hline \multirow{2}{*}{$\begin{array}{l}\text { Berat } \\
\text { Hidup }\end{array}$} & Gianyar & \multirow{6}{*}{56} & 285.75 & 59.37867692 & 0.863 \\
\hline & Bangli & & 287.75 & 62.61317027 & 0.863 \\
\hline \multirow{2}{*}{$\begin{array}{l}\text { Berat } \\
\text { Karkas }\end{array}$} & Gianyar & & 136.7696 & 31.20138062 & 0.148 \\
\hline & Bangli & & 145.7759 & 34.1940957 & 0.148 \\
\hline \multirow{2}{*}{$\begin{array}{l}\text { Persentase } \\
\text { Karkas }\end{array}$} & Gianyar & & 47.80893 & 3.694825708 & 0.000 \\
\hline & Bangli & & 50.48929 & 2.093772461 & 0.000 \\
\hline
\end{tabular}

Tabel 2 Hasil Uji Regresi Pengaruh Berat Hidup terhadap Berat Karkas

\begin{tabular}{llll}
\hline \multicolumn{1}{c}{ Asal Ternak } & R Square & Coefficients & (Constant) \\
\hline Gianyar & 0,870 & 1,022 & 0,420 \\
Bangli & 0,977 & 1,072 & 0,336 \\
\hline
\end{tabular}

Berdasarkan grafik diatas dapat dilihat harga jual karkas sapi bali dari daerah Gianyar yang berwarna biru dan harga jual karkas sapi bali dari daerah Bangli yang berwarna hijau menunjukkan perbedaan. Dimana harga jual karkas sapi bali di daerah Bangli lebih tinggi dibandingkan dengan sapi bali asal Gianyar dengan harga jual per kg Rp 80.000.

Sebagai contoh, apabila Berat hidupnya $328 \mathrm{~kg}$, maka harga jual karkas sapi bali asal Gianyar adalah, 0.420 (328 1.022) $95000=$ Rp. 12.518.789. Sedangkan harga jual karkas sapi bali asal Bangli adalah, $0.336\left(328^{1.072}\right) 95000=$ Rp. 13.379.689, sehingga selisih keuntungannya sebesar Rp 860.000 .

Dari hasil penelitian didapat persentase karkas sapi bali dari kedua daerah asal ternak tersebut menunjukkan perbedaan yang signifikan hal ini dipengaruhi oleh berbagai faktor eksternal maupun internal. Menurut Berg dan Butterfield (1976), persentase karkas dipengaruhi oleh bobot karkas, bobot ternak, kondisi,bangsa ternak, proporsi bagian-bagian non karkas, 
ransum yang diberikan dan cara pemotongan. Komposisi karkas pada ternak dipengaruhi oleh faktor lingkungan (baik yang berupa lingkungan fisiologi maupun nutrisi) dan faktor genetik. jika kondisi lingkungan memungkinkannya. Salah satu faktor lingkungan yang menentukan penampilan potensi genetik adalah sistem pemeliharaan dan ketinggian tempat, karena kedua unsur tersebut ada kaitannya dengan ketersediaan pakan bergizi bagi ternak.

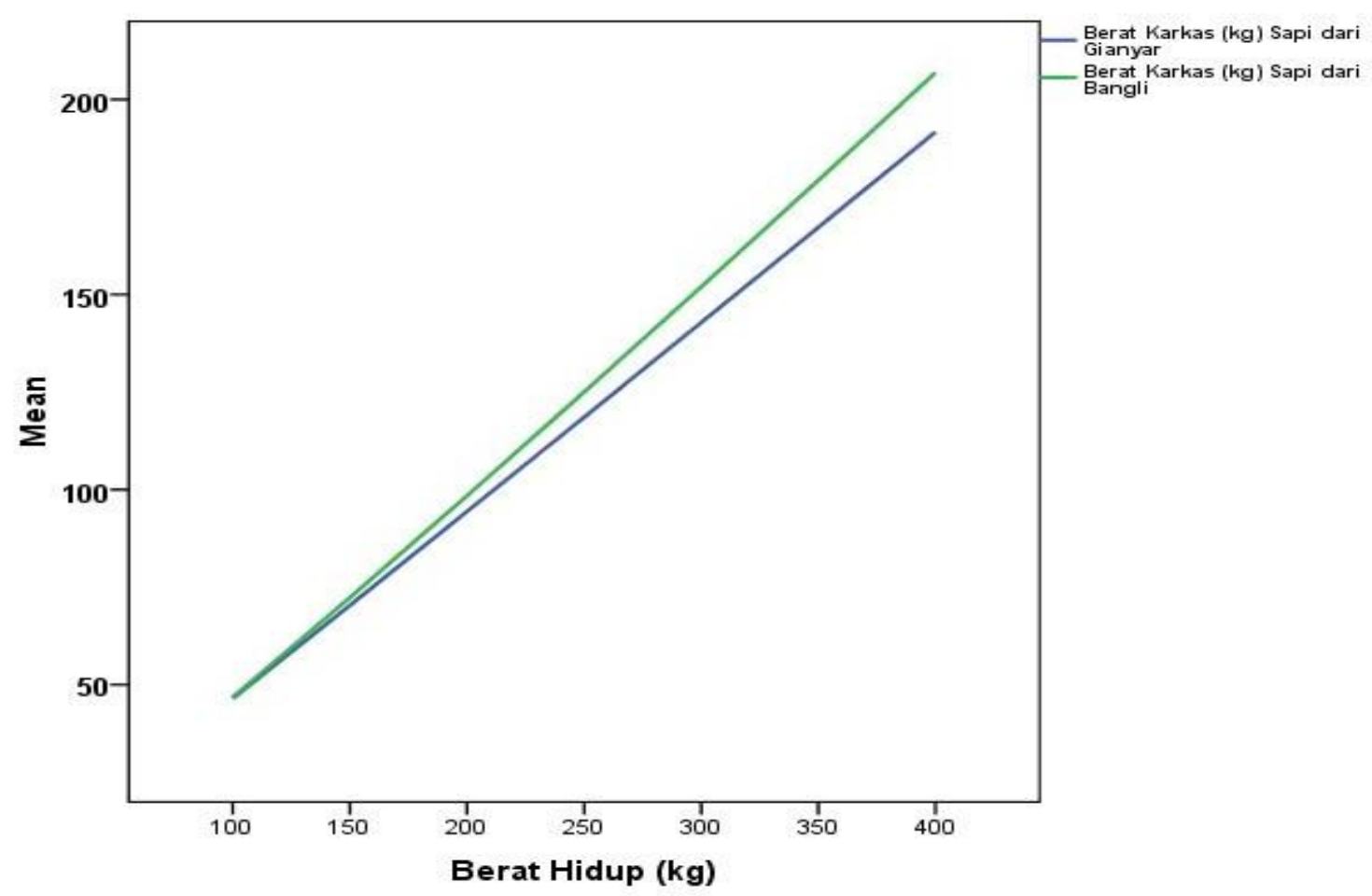

Gambar 1. Grafik berat karkas dari Kabupaten Gianyar dan Bangli

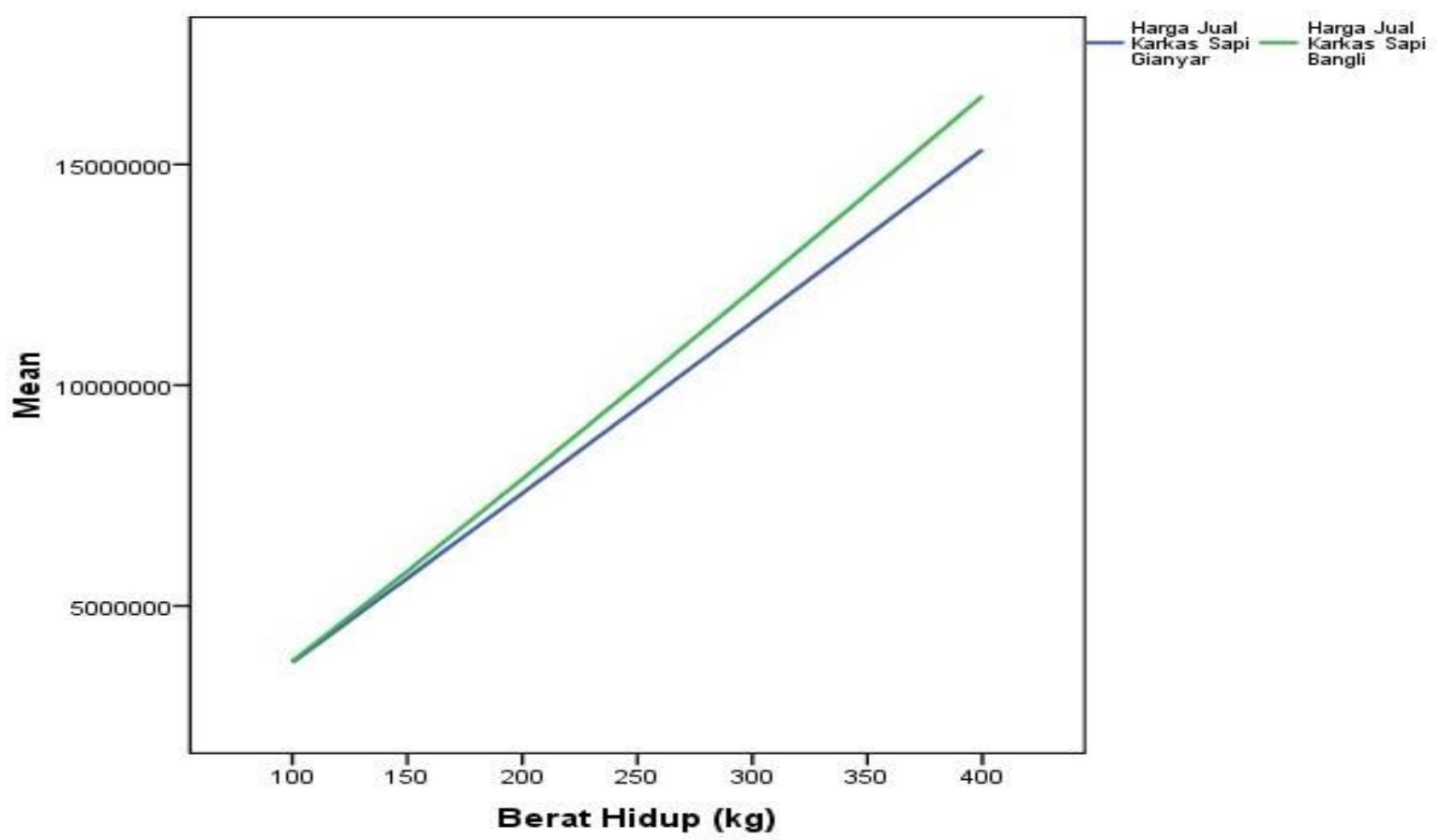

Gambar 2. Grafik harga jual karkas sapi bali dari Kabupaten Gianyar dan Bangli 
Faktor eksternal lain menurut (Sadarman et al., 2007) menyebutkan bahwa sapi yang dipelihara secara ekstensif lebih beresiko terhadap infeksi Fasciola sp. dibandingkan dengan sapi yang dipelihara secara intensif. Ternak sapi yang dipelihara secara ekstensif mempunyai resiko terinfeksi Fasciola sp. yang lebih tinggi karena sapi-sapi tersebut mencari pakannya sendiri sehingga pakan yang diperoleh tidak terjamin baik secara kuantitas maupun kualitasnya serta sesuai dengan kebutuhannya (Kardena et al., 2017)

Faktor lain yang sangat mempengaruhi persentase karkas sapi adalah jenis kelamin, sebagaimana menurut (Saka et al., 2011), pada sapi-sapi jantan amat nyata $(\mathrm{P}<0,01)$ atau amat sangat nyata $(\mathrm{P}<0,01)$ mempunyai berat karkas segar (BKS), FI, dan luas Urat Daging Mata Rusuk (UDMR) yang lebih tinggi daripada sapi-sapi betina.Sedangkan Berat hidup dan Berat Karkas tidak menunjukkan perbedaan yang signifikan. Perbedaan yang tidak nyata ini karena pakan yang diberikan kepada kedua perlakuan kualitasnya sama dan menghasilkan Pertambahan Bobot Badan Harian (PBBH) yang tidak berbeda. Jenis pakan, konsumsi dan komposisi kimia pakan berpengaruh besar terhadap pertumbuhan. Konsumsi protein dan energi yang lebih tinggi akan menghasilkan laju pertumbuhan yang lebih cepat (Soeparno, 2005).

Dengan berat sapi bali sama yang berasal dari Kabupaten Bangli akan menghasilkan karkas dan harga jual karkas yang lebih tinggi dibandingkan dengan sapi bali yang berasal dari Kabupaten Gianyar. Dengan hasil penelitian ini, secara ekonomi para pengepul sapi, para jagal dan pedagang karkas akan lebih untung apabila membeli sapi dengan berat yang sama di Kabupaten Bangli dibandingkan dengan membeli sapi di Kabupaten Gianyar.

\section{SIMPULAN DAN SARAN}

\section{Simpulan}

Simpulan penelitian ini adalah persentase karkas sapi bali yang dipotong di RPH mambal yang berasal dari dataran tinggi dan rendah mengalami perbedaan. Persentase karkas sapi bali asal dataran rendah (Gianyar) sebesar $47.80 \%$ sedangkan persentase karkas sapi bali asal dataran tinggi (Bangli) sebesar $50.48 \%$

Sapi Bali dengan kisaran Berat Hidup yang sama persentase karkasnya lebih tinggi di dataran tinggi Kabupaten Bangli, sehingga menghasilkan harga jual yang lebih tinggi dan lebih menguntungkan dibandingkan dengan sapi bali yang berasal dari dataran rendah Kabupaten Gianyar.

\section{Saran}

Perlu penelitian lebih lanjut mengenai potongan komersial mana yang menyebabkan berat karkas sapi yang berasal dari Bangli lebih berat dari sapi bali asal Gianyar pada berat hidup yang sama.

\section{UCAPAN TERIMAKASIH}

Penulis mengucapkan terimakasih kepada Dekan Fakultas Kedokteran Hewan Universitas Udayana yang telah memfasilitasi pelaksanaan penelitian ini.

\section{DAFTAR PUSTAKA}

Agustina KK, Cahya IMRD, Widyantara GM, Swacita IBN, Dharmayudha AAGO, Rudyanto MD. 2017. Nilai gizi dan kualitas fisik daging sapi bali berdasarkan jenis kelamin dan umur. Buletin Vet. Udayana., 9(2): 156-163.

Besung INK, Watiniasih NL, Mahardika GNK, Agustina KK, Suwiti NK. 2019. Mineral levels of bali cattle (Bos javanicus) from four different type of land in different rearing areas. Biodiversitas, 20(10): 2931-2936.

Berg RT, Butterfield RM. 1976. New Concepts of Cattle Growth. 1st Ed. Sidney University Press, Sidney.

Guntoro S, Suyasa IN, Suprapto. 1997. Berat hidup sapi bali dewasa di bali. Seminar Nasional Peternakan dan Veteriner 1997. 
IM Kardena, Winaya IBO, Adi AAAM, Berata IK, Adnyana IBW, Sukada IM, Agustina KK, Antara PATK. 2017. Patological changes in liver and gall bladder of bali cattle infected by fasciolosis. J. Vet. Med. Anim. Sci., 1(1): 6-10.

Kempster T, Cuthbertson A, Harrington G. 1982. Carcass Evaluation in Livestock Breeding, Production and Marketing. 1st Publication. Granada Publishing Ltd., Grt. Brit.

Sadarman J, Handoko, Febrina D. 2007. Infestasi Fasciola sp. pada sapi Bali dengan sistem pemeliharaan yang berbeda di Desa Tanjung Rambutan Kecamatan Kampar. J. Peternakan 4:37-45.

Sampurna IP. 2012. Analisis Regresi NonLinier Terapan dengan SPSS. Penerbit Pelawa Sari Cetakan I ISSBN:987-6028409-30-8

Saka IK, Mantra IB, Ariana INT, Oka AA, Sriyani NLP, Sentana P. 2011. Karakteristik karkas sapi bali betina dan jantan yang dipotong rumah potong umum Pesanggaran, Denpasar. The Excellence Research Universitas Udayana 2011. Pp. 39-47.

Soeparno. 2005. Ilmu dan Teknologi Daging. Cetakan ke-4. Gadjah Mada University Press, Yogyakarta.

Sriwijayanti DA, Putu IG, Rudyanto MD. 2012. Hubungan antara umur dengan berat karkas depan (fore quarter) ditinjau dari potongan primal sapi bali jantan. Indonesia Med. Vet., 1(2): 202216.

Subekti K, Abbas H, Zura KA. 2012. Kualitas karkas (berat karkas, persentase karkas dan lemak abdomen) ayam broiler yang diberi kombinasi cpo (crude palm oil) dan vitamin c (ascorbic acid) dalam ransum sebagai anti stress. J. Peternakan Indon., 14(3): 447-453.

Yosita M, Undang S, Setyowati EY. 2012. Persentase karkas, tebal lemak punggung dan indeks perdagingan sapi Bali, Peranakan Ongole dan Aurtralian Commersial Cross. Stud. E-J., 1(1): 15. 